Article

\title{
Faith-Based International Development Work: A Review
}

\author{
Dan Heist ${ }^{1}$ and Ram A. Cnaan ${ }^{2, *}$ \\ 1 School of Social Policy and Practice, University of Pennsylvania, 3815 Walnut St., Philadelphia, \\ PA 19104-6214, USA; heist@sp2.upenn.edu \\ 2 School of Social Policy and Practice, University of Pennsylvania, 3701 Locust Walk, Caster Building, \\ Room D-20, Philadelphia, PA 19104-6214, USA \\ * Correspondence: cnaan@sp2.upenn.edu; Tel.: +1-215-898-5523
}

Academic Editor: Robert Wineburg

Received: 10 December 2015; Accepted: 15 February 2016; Published: 25 February 2016

\begin{abstract}
In the wake of the Faith-Based Initiative in the USA, substantial research has resulted in an increased awareness of religious congregations and faith-based organizations as welfare service providers. The next frontier appears to be the role of religious organizations in international social and economic development, a topic that only recently started to attract academic interest. In this paper, we review available literature on the role that religious, or faith-based, organizations play in international social and economic development. We also provide results from our own study of USA international $\mathrm{NGOs}^{1}$ that are faith-based. We divide the paper into the positive contributions of faith-based international NGOs and the drawbacks of these NGOs. We find that faith-based nonprofits constitute almost 60 percent of USA-based international development organizations, and their contribution to international social development is quite considerable. We conclude with a call for further research and nuanced understanding of the role religion plays in international development.
\end{abstract}

Keywords: international development; international social and economic development; religious community; faith based organizations; faith-based NGOs; humanitarian work

\section{Introduction}

Some scholars look at the Faith Based Initiative of the George W. Bush administration as a failure. They conclude that too few congregations joined the ranks of social service providers and, as such, it was much ado about nothing [1]. It is our contention that the errant expectation for congregations and other faith-based organizations to do more welfare provision came from a misunderstanding of the level of welfare service provision from the faith-based community before the initiative took place. The gloomy review of the faith-based initiative failed to account for the already impressive engagement of the faith community in social services provision [2]. In the USA context, the faith community provides more welfare services to more people than any other group of nonprofit organizations. There are numerous congregations as well as faith-based organizations caring for the welfare of Americans even though this is not their primary raison d'etre.

Starting with this perspective, we aim to recognize one area of welfare activity that is also poorly understood - faith-based international social and economic development. This is an important field of

1 In this paper we use the terms nonprofit organizations and NGOs interchangeably. We use these terms as close as possible to the sources we use, acknowledging that, in the US, it is more common to use the term nonprofit, while in many other countries NGO is the more common term. 
social practice in which people and organizations in rich countries, with or without their government, support people and communities in less prosperous countries. In general, the term international development applies broadly to a variety of international activities. In this paper we focus on the efforts of voluntary associations, such as nonprofits and NGOs, specifically those considered faith-based or religious. We attempt to review the historical context and existing literature, discuss some strengths and some weaknesses of faith-based organizations in international social and economic development, as well as carry out a modest empirical investigation on the scope and the role of USA faith-based international development organizations. We identified as many resources as we could find from as many locales as possible though a large share of our findings came from USA-based literature.

\section{Literature Review}

Religion is a wide term that reflects many worldviews. Carole Rakodi contended that '"religion' and the English words used to talk about it, such as faith or belief, do not always translate directly into other religious traditions and languages" ([3], p. 640). While this may be linguistically the case, Muslim and Hindu faith-based development organizations are deeply aware that they originate from and represent a specific faith tradition. In this respect we distinguish between the "substantive" and "functional" definitions of religion [3-5]. We do not follow a substantive definition that is focused on how religion is carried out such as "the sacred", rather we apply the functionalist definition that focuses on "what religion does" for society or a group ([3], p. 638). In this paper, we do not explore the various theological and hermeneutical aspects of religion, but rather how religion or more precisely faith organizations operate in comparison to secular organizations.

International social and economic development is a wide field that focuses on improving basic conditions and the quality of life of people living in developing countries. It can start with country-to-country support, but it is also commonly understood as the activity of private (usually nonprofit) organizations that bring skills, resources, expertise, and goods from a rich environment to a foreign country where it is most needed. In this respect, we do not cover in-country organizations that strive for social and economic development such as local churches or local denominations. There are, however, many schools of thought and understanding concerning the exact definition and characteristics of international social development. This field of activity includes, but is not limited to, economic development, literacy, vocational education, higher education, human rights, political freedom, reduced poverty, secure housing, sustainable development, social infrastructure, health promotion, and quality of life or subjective well-being [6-8]. As is common in the literature, we do not imply that these organizations enhance national or regional development. We assume that they strive to improve quality of life in a sustainable manner that in some cases lead to meaningful development.

Just as international social and economic development is a comprehensive and hard to define concept, so is religion. Some scholars argue that the study of international development in its historical and anthropological context is inseparable from the study of religion [9]. Our focus is not on the religiosity of people and workers but on the organizations that carry out international development work. For the past twenty years, there has been considerable debate over what a faith-based organization is and what a faith-based development organization is [10-12]. In most instances, we opted to go with the definitions used by the sources we reviewed as well as with the organizations we studied. This makes our work easier but it introduces the risk of drawing conclusions from studies that defined faith-based development organizations in different ways.

Dicklitch and Rice proposed that "FBNs [Faith-based NGOs] can be defined as non-state actors that have a central religious or faith core to their philosophy, membership, or programmatic approach, although they are not simply missionaries" ([13], p. 662). An inclusive framework is put forth by Carole Rakodi, whose work demonstrates that "religion and development are not separate spheres of life-they are intertwined and each influences the other" ([3], p. 635). Tara Hefferan, Laurie Occhipinti and Julie Adkins modified a typology put forth by Sider and Unruh-a typology focused on the US context-to consider what role "faith" plays in FBOs working in Latin America and the Caribbean. 
By identifying several key areas for examining faith, the typology allows researchers to consider how "faith and religion are manifested in goals, mission, programming, and funding" along six different faith axes, ranging from "secular" to "faith-saturated" ([14], p. 9). We are far from being able to accurately theorize or even describe the behavior of faith-based organizations. What this study seeks to add is a more comprehensive review of the scope and impact of faith-based development organizations based on extant literature and a modest independent study.

At the G20 Interfaith Summit Meeting 2015 in Istanbul, Peter Howard attempted to elicit what is required of an NGO to be defined as a faith-based organization. First is the notion of the sacredness of life: Faith-based NGOs value the life of everyone. Workers of faith-based NGOs understand people as created in the image of God with transcendent sacredness so that workers can engage with greater honor. Instead of thinking of rights in terms of minimum standards of asylum, food, or education, they think of rights in terms of inclusion, abundance and community. Second, faith-based NGOs have long-term and consistent presence in areas with great needs. This international presence brings with it faith assets such as people, networks, leaders, infrastructure, buildings, and donations. These assets can be mobilized faster, more comprehensively, and wherever needed when compared with public agencies or secular NGOs. Third, faith-based NGOs apply and obey their conscience: Using religious doctrines they advocate for the needy and serve as a voice of conscience. Fourth, faith-based NGOs operate from the standpoint of faith. All world religious traditions emphasize that their faith is an important tool for coping and resiliency. Fifth, faith-based NGOs uphold the theology of mercy and forgiveness. Merciful people and organizations care for and are appreciated by their beneficiaries. Finally, faith-based NGOs emphasize charity. Charity in this context is the willingness to give time, attention, and resources in abundance. Clearly, an empirical investigation will show that not every faith-based NGO fully adheres to all six requisites. In fact, many likely fall short of meeting all six. However, on average faith-based international development organizations may be characterized by these six requisites and often aspire to actualize them. Organizations that follow all six criteria offered by Howard tend to follow their mission with corresponding programs rather than alter programs to pursue funding opportunities [15].

Since the dawn of the 19th century, American Protestant denominations have sent volunteers and paid missionaries to spread their teachings worldwide, including places that were considered unsafe such as Africa, Asia, and Latin America [16]. Many Catholic missionaries and organizations brought technology and knowledge to remote parts of the world for hundreds of years. Numerous religious employees and volunteers took to the road and journeyed long distances spending years trying to evangelize the natives. These missionaries, in addition to spreading their respective religious messages, provided social and healthcare services that formed the foundation of many countries' health and human services infrastructure $[17,18]$. In many countries, the basic universities, hospitals, and other major institutions started with these religious missions. Today, many faith-based international social and economic development organizations provide care and establish civic infrastructure with, or often without, an eye towards proselytization. As Hefferan et al. rightly contended, faith-based development organizations are very diverse and understudied. They noted enormous variation in organizations that fall within the category of faith-based organizations. They suggested that most faith-based development organizations are Christian, however others are Muslim, Jewish, "spiritual" or multi faith, and Buddhist, with a few that are Baha'i, Hindu, or Jain [14].

Unfortunately, there is very little data regarding the role of religion in mainstream social and economic development studies and policy $[3,19,20]$. Kurt Alan ver Beek argued that within the context of international social and economic development, spirituality is taboo. ver Beek searched the three leading development studies journals; Journal of Development Studies, World Development, and the Journal of Developing Areas, for any mentioning of religion or spirituality. He covered the years 1982 to 1998 and found almost no hits. For example, in the Journal of Development Studies there were 46 hits for "gender", 38 for "population", 19 for "environment", one for "religion", and none for "spirituality". 
Most telling is the fact that in all three journals between 1982 and 1998 there was not one article in which religion was a major theme [21]. ver Beek concluded that:

Given the apparently integral link between spirituality and issues central to development, it would seem reasonable that spirituality would occupy a relatively prominent place in development theory and practice. However, the subject is conspicuously under-represented in development literature and in the policies and programmes of development organisations ([21], p. 36).

Ten years after ver Beek's study was published, more publications regarding the nexus between religion and international development were published. However, as Jones and Petersen noted, the majority of these publications suffered from being instrumental in their approach, narrowly focusing on specific faith-based organizations, and were frequently based on normative assumptions rather than empirical assessments. These authors explained "that, in chronological terms, the interest in religion came more from the development industry, particularly the big multilateral and bilateral donors, than from universities and research organisations" ([22], p. 1292). Jones and Petersen acknowledged that more had been written on religion and international social and economic development in the last ten to twenty years. However, despite this, the additional literature was not written systematically, and did not enable full assessment of the role of religion and faith in international development [22]. In studying faith-based development organizations, authors often demonstrate a bias. They either dismiss or wholly support faith-based organizations. While we aim to highlight the unique contributions of faith-based development organizations, we apply a more balanced approach.

Furthermore, it is important to keep in mind the debate over the effectiveness of humanitarian aid in achieving international development goals. Faith-based organizations provide humanitarian services and welfare services designed to reduce suffering and improve living conditions. There is significant debate in development literature about whether humanitarian aid actually helps with development of countries [23]. For the purpose of this paper, we assume the term international development to include the humanitarian and welfare activities of faith-based organizations. We follow the USA's National Taxonomy of Exempt Entities which includes humanitarian organizations in their "International Relief and Development" category [24].

\section{Strengths and Weaknesses}

We begin our investigation with a discussion of suggested strengths and contributions of faith-based international NGOs to international social and economic development. Next, we devote a section to their asserted criticism and review potential weaknesses of faith-based international NGOs. On the strengths and contributions side, we begin with trust in faith-based organizations by the people who are being helped. This is followed by sections on faith networks, religious volunteers for international social and economic development organizations, and funding of international work and the share of the faith community. We then move to an independent study we carried out to compare scope and scale of secular versus faith-based international development nonprofit organizations. We then discuss the impact of faith-based international organizations on the life of their service recipients.

On the side of drawbacks of faith-based international development, we start with issues of proselytization by these faith-based NGOs. This is followed by a discussion on the faith-based NGOs' inclination to work alone and to avoid partnerships and coalitions. The last section of drawbacks deals with religion as a source or contributor to armed conflicts, genocide, terrorism, and other human atrocities. We conclude with a summary as well as suggestions for future research. 


\section{Trust of People Being Helped}

When helping people locally or internationally, forming trust relationships is essential. People that trust the helpers, and do not suspect their motives, are more likely to be transformed and adapt to change. A variety of studies show that faith-based international organizations enjoy strong popular support and trust among the poorest and neediest populations. These organizations and their workers reach people at the grassroots level, speak their language and respect their sentiments and culture. For example, Jones and Petersen reported that "a 2008 Gallup poll showed that $82 \%$ of people in sub-Saharan Africa claimed that they trusted religious organisations more than other societal institutions" ([22], p. 1305). Rick James, based on the World Bank set of studies, concluded that faith-based development organizations are better at reaching out to client population in development than workers of secular organizations [12]. Similarly, Erica Bornstein studied Protestant NGOs in Zimbabwe with a focus on the World Vision national office in Harare as well as in the field. She found that for staff members in the field, faith serves to create bonds of community [25].

Clarke and Jennings contended:

...the language of faith, the religious idiom, frequently better reflects the cultural norms in which the poor and marginalised operate. They are better able to draw such individuals and communities into global discourses of social justice, rights and development, without recourse to the often distancing language of secular development discourse ([26], p. 16).

The problem with these contentions is that few of them were empirically tested. With the exception of the Gallup findings, referenced above, all other sources seem to rely on anecdotal information, and to some extent, on ideological preferences [22]. However, there are very few reports suggesting that religious development workers deterred locals or caused them to distrust the service organizations.

Bruno De Cordier studied Western Muslim FBOs, primarily from the United Kingdom and their work in Central Asia, Iraq, and Pakistan. Some of the studied organizations were large scale and include such organizations as the Islamic Relief Worldwide and Muslim Aid. De Cordier found that Muslim FBOs were more effective in these countries because of their religious beliefs and affiliations. The locals distrusted Western relief organizations and saw them as agents of the corrupt West. Muslim NGOs, alternatively, are viewed as authentic and people are willing to accept help from them [27]. These findings support Jonathon Benthall's assertion that "It is well established that international Christian NGOs can work effectively in Christian parts of Africa through local church networks, and there is surely considerable potential for international Islamic charities to work in a similar way among Muslims" ([28], p. 7).

Robert Leurs reports that, Christian and secular organizations find it difficult to function in Muslim-dominated Kano State. Local residents prefer working with organizations that shared their own religious heritage [29]. Put differently, people on the ground often prefer faith-based providers to secular ones, and if possible those of a faith that locals can relate to.

Deryke Belshaw found in humanitarian work in Africa five advantages FBOs have over secular providers. They can have: (1) the long-term commitment to their memberships as they have served the community for a long time; (2) the majority of the FBO's members are likely to consist of the poorest and most marginalized in developing countries; (3) links to sister organizations that possibly provide funding and expertise; (4) emphasis on the "golden rule" (i.e., treat others as you yourself wish to be treated) as a guide to social relationships; and (5) spiritual and relational experiences that can raise the self-regard and confidence of marginalized people and help them benefit from new opportunities. While not all FBOs live by these standards, they more often describe FBOs as compared with secular ones [30]. Alkire noted the reason why many governments and world financial organizations financially support faith-based development organizations is that these organizations are vital and effective partners in international efforts to reduce poverty. Their perceived closeness to poor communities and their highly motivated staff and volunteers prove them indispensable [31]. 
Just as people on the ground trust religious social and economic development organizations, so do many big funders. In the context of Africa, Paul Gifford noted that "Agencies of official Western aid, reluctant to give to governments they considered corrupt, sought out more reliable local partners, often churches with their extensive networks, grassroots membership, and established structures" ([32], p. 94).

\section{Faith Networks}

It seems that in the past two decades more forces within international social and economic development look to religion to be part of the solution. Possibly the first initiative was the Development Dialogue on Values and Ethics, established in 1998 by James Wolfensohn, then president of the World Bank, and George Carey, then Archbishop of Canterbury. The initiative sought a wide-ranging international and national dialogue among faith and development institutions, with the effort to combat world poverty as the central focus and it evolved into the World Faiths Development Dialogue [33]. The participants realized that the role that faith-based organizations and people played in international social and economic development identified them as important partners in care and that their contributions were unique and significant.

In a related report published by the World Bank in 2000, researchers found that in many developing countries, faith-based organizations develop pervasive networks that often supersede those of local government or other social service providers. It cited examples from Benin to Panama and from Vietnam to Georgia, of religious organizations serving as the dominant care providers and offering services without regard to ethnicity, nationality or religion [34].

Perhaps the most salient example of faith-based networks is the collaborations formed to sustain a prolonged response to the global refugee crisis. According to a report from the United Nations in 2012, there is a great need for more support from international faith-based organizations in response to refugee crises. UN High Commissioner for Refugees António Guterres reported that faith-based relief agencies "can help prevent conflict and address the root causes of displacement, assist refugees in making informed choices in exile, and play a central role in making solutions sustainable by helping refugees integrate in their new communities" [35]. In her qualitative research among Syrian refugees, and the role of religion in their experience, Estella Carpi found that "secular humanitarian responses fail to address the potentialities that lie within engagement with the faiths of displaced groups." She concluded that religious observance among refugees does more than provide a source of community [36].

Many humanitarian efforts involved faith-based organizations working in tandem to address overwhelming issues. This sentiment was officially reported by the United Nations. The World Conference on Religion and Peace (aka the "UN of religions") officially concluded that

Religious communities are, without question, the largest and best-organized civil institutions in the world today, claiming the allegiance of billions of believers and bridging the divides of race, class and nationality. They are uniquely equipped to meet the challenges of our time: resolving conflicts, caring for the sick and needy, promoting peaceful co-existence among all peoples ([37]).

Berger noted that faith-based NGOs are embedded in extensive networks of both faith-based organizations and secular NGOs that allowed them to be successful in various important campaigns such as the 2000 jubilee year. This massive campaign started as a movement to advocate for international debt relief. The organizers used the biblical term of debt relief (jubilee) to gain support, predicting that in the year 2000 most poor countries would be free of their debt. According to Berger, they were successful and received support from all across the political map. In 1996, the International Monetary Fund (IMF) and World Bank announced a new initiative with the aim of ensuring that no poor country faced a debt burden it could not manage. Berger concluded that "Religious nongovernmental organizations were also active in the Nobel Prize winning International Campaign to Ban Landmines 
and are actively involved in the 1000-plus member NGO Coalition working for the advancement of the International Criminal Court" ([19], p. 20). Similarly, although our focus is not on within-country development efforts, many faith-based international NGOs have the advantage of local congregations that they can mobilize in their development and welfare services. Having supporting allies on the ground is a strategic advantage that many secular NGOs lack.

\section{Volunteers for International Social and Economic Development}

The number of international nonprofit and social agencies relying on the help of volunteers has grown enormously in recent decades. International volunteering utilizes volunteers who are not citizens of the country in which they are working. In the past fifty years, the number of international religious volunteers and service providers has dramatically increased. In the last half century missionary work did not plateau but expanded. Micklethwait and Wooldridge suggested that missionary work expanded with reduced cost of travel as new opportunities arose. Several geopolitical events (such as the end of colonialism, the fall of most communist regimes, and the spread of democracy that has weakened the control of state-sponsored religions) opened many countries to the presence of religious volunteers. However, not all religious groups are equally involved in international work [38]. Hanson and Xiang noted "the US is the largest single exporter of Protestant Christianity" ([39], p. 6). Similarly, Brouwer, Gifford and Rose discovered that Protestant denominations with the most restrictive religious doctrines and distinctive worship practices often engage more volunteers worldwide and also have enjoyed the most membership growth [40].

Rieffel and Zalud estimated that, in 2006, out of 43,000 Americans engaged in long-term international volunteering, 8000 were affiliated with specific faith-based organizations such as Habitat for Humanity, Catholic Relief Services, and the Presbyterian Hunger Program [41]. However, this estimate excludes missionaries whose primary goal is to propagate the religion of the sending agency such as the thousands of missionaries sent annually by The Church of Jesus Christ and Latter-day Saints (LDS Church) or the Assemblies of God. Moreau, Corwin, and McGee reported that in 2001 alone, an estimated 350,000 Americans travelled abroad with Protestant missionary agencies for periods that may range from a week to over a year [42]. Furthermore, these estimates did not take into account the many religiously-motivated international volunteers who are serving in secular organizations [43]. Sadly, there are no equivalent statistics regarding religious international volunteering from European countries.

Benjamin Lough studied international volunteers from the USA and determined that young adults aged 15-24 years were those most likely to engage in unpaid service abroad, followed by those approaching traditional retirement age (55-64 years). This was likely the result of the time and cost required from international volunteers. Similarly, two-thirds of international volunteers were living in higher earning households ( $\$ 100,000$ or more). Lough also found that almost half $(45 \%)$ of those volunteering abroad were "associated with a religious organization", a higher rate of religious affiliation than domestic volunteers (estimated at around 35\%) [44].

When discussing international volunteering, there are three key types to consider. One type is known as "volunteer tourism". McGehee and Santos defined volunteer tourism as "utilizing discretionary time and income to travel out of the sphere of regular activity to assist others in need" ([45], p. 760). Those who can afford the time and cost fly to a remote community and provide a needed service such as building a structure, monitoring an election, providing medical care, digging a well or paving a path in a rain forest. A second type of international volunteering has to do with responding to a natural disaster or other emerging crises. Many faith-based and social organizations are ready to respond to any humanitarian crisis. This type of volunteering usually involves civil professionals (from construction experts to medical workers) who are trained in relief work and who are willing to be mobilized on short notice [46,47].

The third archetype of international volunteering may be called long-term deployment. Long-term volunteers commit to a relatively long period of service (ranging from a few months to many years) 
and relocate to a place where they are needed. In the secular world, one of the most commonly known types of long-term volunteering is the Peace Corps. In 2006, for example, there were 7800 Peace Corps volunteers who spent lengthy periods of time outside of the USA [41]. Many faith-based organizations also send volunteers for long periods of time to help meet local needs and/or for proselytizing. As noted above, their numbers are significant and if we include missionaries they are the majority of long-term deployed volunteers.

Lough found out that when looking at the type of main organizations for volunteers who spent all or almost all of their time volunteering internationally from 2007 to 2012, 45.4\% were religious organizations. The next most common type of international organization were social and community service organization (10.8\%) [44].

\section{Funding for Faith-Based International Development}

According to the National Center for Charitable Statistics, organizations categorized by the National Taxonomy of Exempt Entities (NTEE) Code Q, international affairs, reported a total of $\$ 40.1$ billion in gross receipts in 2014 [24]. Much of this came from government grants, and investments. Giving USA 2015 reported that $\$ 15.1$ billion of this funding came from private donations [48]. The four international development organizations with the largest amount of private support in 2013 were all faith-based organizations: Food for the Poor with $\$ 891.4$ million (mostly from donations in kind), World Vision with $\$ 826.9$ million, Feed the Children with $\$ 613.7$ million, and Compassion International with $\$ 596.1$ million. These four organizations account for $20 \%$ of the total donations given to international affairs. As a trend, giving to the international NGOs declined gradually over the last seven years from its peak in 2008 at $\$ 22.26$ billion. This trend is a result of the impact of the recession on charitable giving [49].

Elizabeth Ferris suggested that in the early 2000s "the church related agencies associated with the World Council of Churches mobilized over US $\$ 1$ billion per year for relief and development and the members of the Caritas Internationalis family, in 162 countries, mobilized at least that amount" ([50], p. 313). These sums do not include locally raised funds, the many religious groups that not affiliated with these two large organizations, and religious donations to secular organizations. This amount is similar to the sum reported by Dicklitch and Rice who estimated that combined the major faith-based international social and economic development organizations spend about two billion dollars a year [13].

One source of private funding for international development comes from collective donations. It is not uncommon for congregants in various faith traditions to be asked during a worship service to make a financial donation to an international relief effort sponsored by or associated with that place of worship. The National Congregations Study (NCS), drawn from a representative sample of U.S. places of worship, found in 2006 that nearly half (41.6\%) of religious congregations held gatherings to consider "travel to another country to provide assistance to people in need" [51]. Moreau, Corwin, and McGee reported that donations to Protestant missionary agencies totaled $\$ 3.75$ billion, a $44 \%$ increase in five years [42].

Smillie and Minear noted that while both secular and faith-based international social and economic development organizations receive money from governments, faith-based organizations limit this source of income to keep their independence while secular organizations are almost fully dependent on government support and can be viewed as an arm of government. These authors suggested that, for example, $70 \%$ of funds for Action Contre la Faim in France came from official sources, while World Vision USA received only $23 \%$ of its income from the government in 2001. Oxfam GB received $28 \%$ from the government and the Lutheran World Federation just 20\% [52].

International development attracts larger donors as well. Sixty percent of corporate donors look overseas to make a difference, indeed $57 \%$ of the Fortune 500 companies gave to internationally based charitable organizations [49]. While corporations can be lucrative sources of philanthropy, it is also 
important to recognize that corporate giving strategies often focus on improving conditions in regions where the firm hopes to develop markets as well.

As an example of the resources that one faith-based organization can garner, Paul Gifford reported that in 2008, Caritas international (the Catholic international development organizing body) alone employed 440,000 paid staff and 650,000 volunteers, and had a combined estimated worth of US $\$ 5.5$ billion. He also noted many smaller Catholic organizations that support international development such as the British MIVA (Missionary Vehicle Association) that purchased and distributed some 3000 ambulances, special cars, boats and so forth). He concluded that "It is not necessary to list more. The list is virtually endless, and the extent of Western funding is virtually impossible to discover, because so much is invisible as it is personal" ([32], p. 93).

\section{The Scope of Religious vs. Secular International Development Organizations}

We made the case that people in the developing countries often prefer faith-based NGOs especially if they match their own faith. We also documented the impressive volume of volunteers and funding that comes from and through religious international development. We noted that most of the very large international social and economic development organizations are faith-based ones. The one thing we did not yet document is the ratio of faith-based $v$ s. secular international development organizations. In this case, we decided to carry out our own investigation.

Our aim was to identify faith-based international development within a larger pool of organizations associated with international social and the economic development. Unfortunately, data were only available for USA-based international organizations. Using data from the National Center on Charitable Statistics, we looked at those organizations that fall under the NTEE category of Q3 International Development organizations [24]. With the help of NCCS and Jon Durnford at DataLake Nonprofit Research, we found that 59\% (3505) of international development organizations were faith-based organizations. Although constituting a majority of the number of organizations, faith-based nonprofits only accounted for an estimated $40 \%(\$ 12,493,572,141)$ of gross revenues, and $30 \%(\$ 9,702,649,428)$ of the total assets of Q3 organizations that filed a form 990 (annual tax report for nonprofits organizations) with the Internal Revenue Service. The prevalence of religiously affiliated organizations in international development emphasizes the need for further research in this field.

In order to get an idea of the kinds of services being provided by international NGOs, we took a small sample of organizations, based on their self-identification, divided them into religious or secular and collected information provided on their websites. We recognize that information on organization websites is provided for publicity purposes and can be exaggerated. Considering the dearth of empirical data on faith-based organizations in international development and the limited scope of this article, we felt that this would be one feasible starting point. Using a random sample of Q3 organizations from the NCCS and Guidestar websites, we went to the organizations' websites reviewing their mission statements and mining for information [24,53]. If we found terms related to religion like "faith", "Christian", "Jewish", or "God", we categorized them as faith-based organizations. We took a quota sample of 21 faith-based organizations, as well as a similar sample of secular organizations. Even this small sample of organizations covered a wide range of services. Almost every organization was involved in more than one activity. The types of services included, but were not limited to: food provision, clean water, clothing, refugee services, education, medical, orphanages, microfinance, infrastructure, advocacy, and technology. As we compared the kinds of activities that each type of organization was involved in, we found that faith-based organizations on average provided significantly more kinds of services (4.2 types of services per organization) compared to the secular organizations (2.6 types per organization, $p<0.05$ ). As such, faith-based international organizations were covering wider range of services while secular ones tend to specialize in limited number of service areas. The implications for this finding are unclear, further research may consider how providing more types of services per organization relates to levels of collaboration. 
As we compared what kinds of services were provided by faith-based and secular organizations, there were no significant differences. In other words, faith-based organizations were not predominant providers of one type of service like clean water or clothing. We also compared the locations of services provided by each type of organization, but the websites provided this information in inconsistent formats, some reporting work in "Africa" and others focusing on specific cities or villages. Even after attempting to compare by country or region, no clear patterns emerged from the data. Overall, a comparison of websites of international NGOs suggests that the differences between faith-based and secular NGOs are not readily distinguishable online.

\section{Impact on the Ground}

Maybe the most difficult task is to assess the "on the ground" impact of faith-based international social and economic development organizations. In this respect, we rely on and quote from Narayan et al. These authors reviewed all the available World Bank country reports and came up with the following summary:

In some regions NGOs with the strongest presence are religiously affiliated. This is the case, for instance, in Benin, where these organizations function as one of the most visible and widely distributed institutional safety nets for the poor. The majority of the orphanages are run by Catholic sisters, the only country-wide nutritional program is managed by Cathwell (Catholic Relief Services), and nuns and priests have set up several programs to assist the sick, the abandoned, and the destitute. In Cotonou, the Catholic Church is arguably the strongest presence helping the most vulnerable (Benin 1994). In Panama (1998) over half the communities acknowledge churches and schools for their support. In Vietnam (1999) poor Catholic households in need of support turn to the church. In Georgia, the Russian Orthodox Church and the International Orthodox Churches Charities run soup kitchens for the elderly and disabled and distribute food and medicines (Georgia 1997). These efforts were praised by local people who noted that "although local Armenian and Georgian priests had organized the distribution, they did not reject any minority, including Jews, Greeks or Russians" (Georgia 1997). In Pakistan (1993) the PPA reports "a deeply entrenched tradition of private charity and welfare reinforced by Islamic religious obligation." Mosques and shrines are valued as sites of charity. Ashrams are mentioned in some places in India as places of refuge for the poor ([34], p. 134).

Narayan et al. also searched for negative examples of the work of faith-based international social and economic development organizations. They managed to find some examples but they were all related to small highly evangelical groups whose overall share of international social and economic development was marginal. These evangelical groups often put proselytization ahead of service provision and, as such, agitated local communities and their traditions. We will discuss this issue in greater detail below. It is important to note the negative side of faith-based international social and economic development, however, we should keep in mind that its magnitude is dwarfed in comparison with the size of faith-based international social and economic development support. This is what Narayan and colleagues reported:

While faith-based groups are often mentioned as sources of help, in Panama "discussions revealed that Christian sects have occasionally had a divisive effect among indigenous communities. In one Kuna island community, for example, part of the community refuses to recognize the Asambleas de Dios, with their congress not wanting any more churches because the proliferation of churches is seen as fragmenting the community into small units ... If the community is divided, those divisions are reflected in church organizations" (Panama 1998)...Georgians expressed mixed sentiments toward the role of religious organizations that required them to switch faiths. The report notes, "This issue perplexed an Azerbaijani family, who finally decided to accept aid from Jehovah's 
Witnesses, despite initial reluctance to accept a pacifist faith whose tenets they might have to violate if members were called to serve in the Georgian army. They compromised by deciding the 'less important' family members-mother and sister-would use the aid" (Georgia 1997) ([34], p. 140).

In many parts of the world, faith-based organizations are the major source of care in developing areas. For example, Bennell, Harding, and Rogers-Wright reported that in Sierra Leone, about $75 \%$ of primary schools are owned and managed by FBOs [54]. Daun reported that in Africa, Christian (Catholic and Protestant alike) missionaries brought the concept and practice of formal education and the establishment of educational institutions [55]. Later, the spread of Islam led to the provision of education throughout the continent. These key world religious influences are the foundation of educational facilities and institutions throughout Africa. The late Nelson Mandela told the audience in the World Council of churches in 1998 "My generation is the product of missionary education. Without (that) I would not be here today. I will never have sufficient words to thank the missionaries for what they did for us" [56].

Gifford reported that in Africa "Historically, churches were far more involved in education than colonial governments" ([32], p. 85). Indeed, according to Hastings in 1945, in the areas of tropical Africa that were ruled by Great Britain, $96.4 \%$ of the school-attending children did so through a mission school [57]. Gifford found that "In Africa in 2009 there were claimed to be over 12,000 Catholic infant schools, 33,000 primary schools, and almost 10,000 secondary schools, plus about twenty universities" ([32], p. 86). The qualification in the above sentence refers to the fact that many of these schools are currently financed by African governments. Gifford also demonstrated that among university students the majority graduated from Christian schools, and where there are national tests, students from religious schools pass at a significantly higher rate [32].

Gifford assessed that "In Africa, in 2010, the Catholic Church operated 16,178 health centers, 1074 hospitals, 5373 out-patient clinics, 186 leper colonies, 753 homes for the elderly and the physically and mentally disabled, 979 orphanages, and 2947 educational and rehabilitation centers" ([30], p. 90). He also reported that half of all AIDS-related organizations in Africa are provided by Catholic organizations. Gifford concluded that in health "As with schools, the church led the way, long before governments" ([32], p. 91).

At least in one occasion, in 1947, the Nobel Peace Prize was awarded to two Quaker organizations-the Friends Service Committee in London and the American Friends Service Committee in Philadelphia-for humanitarian service and dedication to peace and nonviolence. Other religious leaders such as the Dali Lama, Mother Teresa, and Bishop Desmond Tutu also received the Nobel Peace Prize.

There are very few empirical studies of effectiveness comparing religious and secular development organizations. One related study compared Christian and secular micro-finance organizations. Mersland, D'Espallier and Supphellen reported that "Christian MFIs have significantly lower funding costs and consistently underperform in terms of financial profit indicators. Contrary to our hypotheses, Christian MFIs are as efficient in assuring loan repayment and their average loan sizes are on par with those of their secular peers" ([58], p. 145). It is not our contention that faith-based international development organizations should be considered superior to their secular counterparts. The mere fact that they add international development services that otherwise would not have been provided is an important contribution that needed to be assessed and better understood.

\section{The Issue of Proselytization}

In a previous paragraph, we noted that corporate support for international development is often a means to capture markets and obtain gains. The same is often said about faith-based international development which is often perceived as a means for converting locals and gaining new supporters. It is no secret that many evangelical development organizations are hoping for converts and may even try to convert local service recipients. Two points should be made in this respect. 
First, both secular and faith-based organizations are engaged in some form of conversion. They both try to increase the education of locals, make them more capable to handle complex issues, and think more like people in the West. Some faith-based organizations add a faith element while others do not. However, all organizations aim to transform the way people in developing countries think and operate. In this respect, Berger noted:

From the start, NGOs have been a moral entity. They have challenged the "Wrong" in favor of the "Right" and sought to alter inequitable distributions of power and resources in favor of the disenfranchised. Religious NGOs, however, recognize the religious rather than purely "reasoned" origin of the values, which they seek to realize. The Golden Rule "Love thy neighbor", underpinning all religious traditions, exhorts believers to be concerned with the condition of others, thereby bringing religious practice into the public sphere ([19], p. 19).

Second, data from numerous sources suggests that most faith-based development organizations focus on service delivery rather than on proselytization. For example, Barr, Fafchamps, and Owens reported that in Uganda "The activities of surveyed NGOs and the methods they use to spread their messages (workshops, open air speeches, and door-to-door visits) appear similar to the traditional charitable works performed by churches. However, there is very little evidence to suggest that the surveyed NGOs are, in fact, 'churches in disguise': only 30\% of surveyed NGOs are faith based, and the content of their messages is highly varied" ([59], p. 664).

Similarly, Dicklitch and Rice study FBOs in Africa highlighting the Mennonite Central Committee (MCC) which operates in twenty African countries. The authors argued that "the MCC successfully contributes to development initiatives in 20 African countries because of its philosophical and programmatic approach, which focuses squarely on accountability, a holistic approach to basic human rights, and a listen and learn approach that encourages self-help initiatives and empowerment rather than a culture of dependency" ([13], p. 661). These authors also contend that workers of the MCC explicitly avoided acts of proselytization, allowing their care and actions to speak for them. The authors reported that "Although it is an FBN, the MCC is not a traditional missionary organization. It does not seek to proselytise, although it works with mainly local faith-based organizations such as Presbyterians, Lutherans, and United Methodists" ([13], p. 668).

An interesting perspective on proselytization is offered by Robert Woodberry. He studied a large number of countries in which missionaries were actively proselytizing in the 19th and early 20th century versus countries in the same developing world where missionary work was prohibited. Woodberry found that the missionary movement had strong, positive influence on liberal democratization. Countries open to missionaries ended up upholding democratic principles and experienced democratic government significantly more so that countries not exposed to missionaries [60]. In another perspective on proselytization, Dena Freeman explains how the Pentecostal movement in Africa seeks to transform individual converts, helping them to break away from traditional cultural norms, thereby liberating themselves to pursue wealth and personal progression [61]. The issue of proselytization must be recognized when discussing religion and international development, though an understanding of its scope and consequences should be further studied.

\section{Coordination and Isolation}

In addition to proselytization, faith-based international NGOs are often accused of acting alone and refusing to collaborate with other organizations from different faith traditions, secular NGOs, and public agencies. The logic of this criticism is that resources are limited, and if more coordination and collaboration were to take place, NGOs could maximize their beneficial impact, minimize waste and overlap, and more people could be served at lower cost. While there are no studies that comprehensively address this topic, it seems like a given in many public discussions. Benedetti suggested that the less fundamentalist faith-based NGOs are more willingly participate in partnerships and coalitions, while the more religiously fundamentalist NGOs are less likely to collaborate [62]. 
Ghandour for example, reported a case in which moderate Islamic NGOs actively collaborated with secular and moderate Christian NGOs. However, again, there are not enough empirical data to substantiate this assertion [63].

It should be noted that coordination and collaboration are very complex and problematic issues among all types of international NGOs, not only religious [64,65]. NGOs fear full partnership as it may mean downsizing, inability to claim success, loss in donor support, and possible mission drift. In a report for Congressional Research Services, Marion Lawson noted that "several aid officials have suggested that aid workers are too busy to devote time and attention to coordination, a task that most are not evaluated on as part of their individual performance reviews" ([66], p. 17). Lawson's report provides a long list of the benefits and barriers to international development collaboration and assesses that it is problematic to the sector as a whole and not to one sub-sector or another.

Clearly there is a need to develop new and nuanced models to guide intra and cross- sectoral partnerships and collaborations to avoid pitfalls and better serve those in need. It is however, a joint challenge to faith-based NGOs and the other organizations in the field of international social and economic development.

\section{Religious Groups and Their Contribution to Tension and Terrorism}

The final criticism levied against faith-based NGOs in the international development context is that they contribute to tensions and conflicts. The current terrorist activities taken by ISIS, for example, are seen as the result of people's adherence and blind commitment to one faith tradition. Hasenclever and Rittberger noted "Often the political resurgence of religious communities is accompanied by violent clashes in and between nations. Take, for example, the bloody conflicts in Algeria, Bosnia, East-Timor, Kashmir, Nigeria, Palestine, and Sri Lanka, to name but a few" ([67], p. 641).

Terrorism is often affiliated with religious groups [68]. However, contending that world conflicts and military harm is the outcome of religious fanaticism is to ignore the fact that such conflicts are complex phenomena involving motives that are rooted in political, economic, territorial, cultural, and psychological in nature. Religion is a force that can galvanize and unified people to the point of extremism [69]. Hasenclever and Rittberger, who above listed many religious-based conflicts also argued that "although differences in religious creed are hardly ever a genuine source of violent clashes, under certain conditions, they have the potential to escalate conflict behavior" ([67], p. 642).

In the context of international social and economic development, the faith-based organizations are countering the impact of extremist groups. There are many ways by which people can actualize their faith. Hatred and terrorism is one way; serving people in need is another way. The faith-based international development organizations are emphasizing the latter.

\section{Discussion and Conclusions}

International social and economic development is an important field of care in which people and organizations in rich countries, with or without their government, support people and communities in less prosperous countries. The great divide between developed and developing countries, also known as the North-South division, calls on people in the rich parts of the world to assist those in poorer areas. Unfortunately, international social and economic development is not a high priority for most people and financial support for this noble aim has declined since the last recession of 2008.

In the realm of international affairs, religion has often been seen as a divisive influence, creating conflict between once peaceful neighbors, leading to war between nations and peoples. Critics suggest that religion gives a license and even encouragement to kill all that are different, as is currently highlighted in mass media with regards to ISIS (Islamic State of Iraq and Syria). For many in the public the only purpose of faith-based international development is to gain new members and become more influential. The distrust of religious people and organizations is partially based on past transgressions and modern day focus on extreme groups. Advocates of international development in contrast claim long-standing traditions of social improvement and unique advantages to address the most pressing 
social problems. Government officials and diplomats often ask, "What value does faith bring to the realm of international development" [70]? This paper is an attempt to elucidate the various elements that should be considered in answering that question.

Following ver Beek, we started this article by stating that the involvement of the faith community in international social and economic development is underreported and understudied [21]. In this article, we documented some of the involvement of faith-based organizations in the field of international social and economic development. Until the year 2000, there were no studies that focused on the role of the faith community in contributing to international social and economic development. Since 2000, more studies were focusing on faith-based involvement in international social and economic development, but most of them were case-studies, anecdotal accounts, and authors' reflections. Still, a picture had emerged. We now know that in many parts of the world, the key international social and economic development organizations are religious. In the United States, the four largest development organizations are faith-based and these organizations alone account for $20 \%$ of all funds devoted to US-originated international social and economic development. We also know that a large number of volunteers who constitute the majority of international development workers are working in a faith-based organization or are being motivated by religious conviction. Findings from Europe, though not as encompassing as the data from the USA are, suggest similar trends.

We divided most of the article into two unequal parts. The first views at faith-based international development organizations favorably and reports their strengths and importance. We also discussed in this section some sources that disagree with the rosy picture of the faith-based international development organizations. The second part looks at the drawbacks of these organizations and discusses the criticism directed at faith-based international development organizations. Here again, we also cite sources contending against the criticism.

Our own empirical investigation found out that of all organizations that are categorized as international development $59 \%$ can also be defined as faith-based. This empirical investigation definitely indicates the importance of faith-based factors in international social and economic development.

At this stage, more focused investigation should be conducted to assess real impact of these organizations on the ground, including the financial and employee/volunteer contribution. Our findings, so far, suggest that faith-based international social and economic development is similar to welfare services provided by congregations in the USA. Faith-based NGOs are heavily involved in direct relief and development, the majority of them are not on the ground for proselytization purposes, and they go unnoticed and underappreciated. The faith-based international development field is taken for granted and rarely documented. Ultimately, faith-based organizations, like their secular counterparts, are attempting to alleviate the negative life conditions of people in the communities they are serving.

Deneulin and Rakodi reviewed the field of faith-based international development 30 years after the publication of a special issue of World Development on "Religion and Development". They noted that much is still unknown. They suggested two broad implications. "First, the assumptions of secularization and secularism that supposedly define the relationships between religion, society, and politics have to be revisited. Second, development studies must recognize that religion is dynamic and heterogeneous" ([4], p. 45). After reviewing the literature and conducting our study, we concur. Faith plays a key role in international development work, some of which is clearly recognizable and some very latent. Clearly, further study of this field is warranted.

It was surprising that there is no one comprehensive source about the scope and magnitude of faith-based international social and economic development. Most accounts we found were limited to one country or one region and even these were limited to one faith tradition or one sub-set of activities such as hunger relief or health prevention. On the flip-side, it was also surprising that there are few sources that attempted to reflect the wide diversity among faith-based international development organizations. Those NGOs affiliated with a distinct faith tradition may differ from the unaffiliated, 
and those that are focused on one country may differ from the more globally focused ones. We hope that we brought some clarity and insight, but acknowledge that much work is still ahead.

Author Contributions: The authors worked together on all parts of the paper, and both equally contributed to the content and writing.

Conflicts of Interest: The authors declare no conflict of interest.

\section{References}

1. Mark Chaves, and Bob Wineburg. "Did the faith-based initiative change congregations?" Nonprofit and Voluntary Sector Quarterly 39 (2010): 343-55. [CrossRef]

2. Ram A. Cnaan, and Daniel W. Curtis. "Religious congregations as voluntary associations: An overview." Nonprofit E Voluntary Sector Quarterly 42 (2013): 7-33. [CrossRef]

3. Carole Rakodi. "A framework for analysing the links between religion and development." Development in Practice 22 (2012): 634-50. [CrossRef]

4. Séverine Deneulin, and Carole Rakodi. "Revisiting religion and development: 30 Years on." World Development 39 (2011): 45-54. [CrossRef]

5. Emma Tomalin. Religions and Development. London: Routledge, 2013.

6. Richard J. Estes. "Developmental social work: A new paradigm for a new century." Paper presented at the 10th International Symposium of the Inter-University Consortium for International Social Development, Cairo, Egypt, 28 June-2 July 1998.

7. Mark Lusk. "International social development and counter-development." Journal of Comparative Social Welfare 26 (2010): 165-76. [CrossRef]

8. Brij Mohan. Fallacies of Development: Crises of Human and Social Development. New Delhi: Atlantic, 2007.

9. Philip Quarles van Ufford, and Matthew Schoffeleers, eds. Religion and Development: Towards an Integrated Approach. Amsterdam: Free University Press, 1988.

10. Heidi Rolland Unruh, and Ronald J. Sider. Saving Souls, Serving Society. New York: Oxford University Press, 2005.

11. Matthew Clarke. Development and Religion: Theology and Practice. Cheltenham: Edward Elgar, 2011.

12. James R. Rick. "What is distinctive about FBOs? How European FBOs define and operationalise their faith." Praxis Paper 22, INTRAC, 2009. Available online: http://www.intrac.org/data/files/resources/ 482/Praxis-Paper-22-What-is-Distinctive-About-FBOs.pdf (accessed on 27 October 2015).

13. Susan Dicklitch, and Heather Rice. "The Mennonite Central Committee (MCC) and faith-based NGO aid to Africa." Development in Practice 14 (2004): 660-72. [CrossRef]

14. Tara Hefferan, Laurie Occhipinti, and Julie Adkins. "Faith-based organizations, neoliberalism, and development: An introduction." In Bridging the Gaps: Faith-Based Organizations, Neoliberalism, and Development. Edited by Tara Hefferan, Julie Adkins and Laurie Occhipinti. Lanham: Lexington Books, 2009, pp. 1-34.

15. Peter Howard. "Humanitarian aid organizations and sustainable development." Paper presented at the G20 Interfaith Summit Meeting, Istanbul, Turkey, 18-20 November 2015.

16. Robert D. Woodberry, and Timothy S. Shah. "The pioneering Protestants." Journal of Democracy 15 (2004): 47-61. [CrossRef]

17. Philip G. Altbach, and Toru Umakoshi. Asian Universities: Historical Perspectives and Contemporary Challenges. Baltimore: Johns Hopkins University Press, 2004.

18. Morton H. Fried. "Reflections on Christianity in China." American Ethnologist 14 (2009): 94-106. [CrossRef]

19. Julia Berger. "Religious nongovernmental organizations: An exploratory analysis." Voluntas 14 (2003): 15-39. [CrossRef]

20. Gerrie Ter Haar, and Stephen Ellis. "The role of religion in development: Towards a new relationship between the European Union and Africa." The European Journal of Development Research 18 (2006): 351-67. [CrossRef]

21. Kurt Alan ver Beek. "Spirituality: A development taboo." Development in Practice 10 (2000): 31-43. [CrossRef]

22. Ben Jones, and Marie Juul Petersen. "Instrumental, narrow, normative? Reviewing recent work on religion and development." Third World Quarterly 32 (2011): 1291-306. [CrossRef]

23. Henrik Hansen, and Finn Tarp. "Aid effectiveness disputed." Journal of International Development 12 (2000): 375-98. [CrossRef] 
24. National Center for Charitable Statistics. "Public Charities: NTEE = Q3 (International Development, including NTEE subcategories)." NCCS.org. Available online: http:/ /nccsweb.urban.org/PubApps/show OrgsByCategory.php?close=1\&ntee=Q3 (accessed on 27 October 2015).

25. Erica Bornstein. The Spirit of Development: Protestant NGOs, Morality, and Economics in Zimbabwe. Stanford: Stanford University Press, 2003.

26. Gerard Clarke, and Michael Jennings, eds. Development, Civil Society and Faith-based Organizations. London: Palgrave Macmillan, 2008.

27. Bruno De Cordier. "Faith-based aid, globalization and the humanitarian frontline: An analysis of Western-based Muslim aid organisations." Disasters 33 (2009): 608-28. [CrossRef] [PubMed]

28. Jonathon Benthall. "The overreaction against Islamic charities." ISIM Bulletin 20, Institute for the Study of Islam in the Modern World, Leiden, The Netherlands, 2007. Available online: https://openaccess. leidenuniv.nl/bitstream/1887/12453/1/Review_20.pdf (accessed on 27 October 2015).

29. Robert Leurs. "Are faith based organisations distinctive? Comparing religious and secular NGOs in Nigeria." Development in Practice 22 (2013): 704-20. [CrossRef]

30. Deryke Belshaw. "Enhancing the development capability of civil society organisations, with particular reference to Christian faith-based organisations (FBOs)." June 2005. Available online: http:/ /www.sarpn. org/documents/d0002355/CFBOS_Belshaw_June2005.pdf (accessed on 27 October 2015).

31. Sabina Alkire. "Religion and development." In The Elgar Companion to Development Studies. Edited by David A. Clarke. Cheltenham: Edward Elgar, 2006, pp. 502-9.

32. Paul Gifford. Christianity, Development and Modernity in Africa. London: Hurst, 2015.

33. Katherine Marshall. "Development and religion: A different lens on development debates." Peabody Journal of Education 76 (2001): 339-75. [CrossRef]

34. Deepa Narayan, Raj Patel, Kai Schafft, Anne Rademacher, and Sarah Koch-Schulte. Voices of the Poor: Can Anyone Hear Us? Washington: World Bank Publications, 1999. Available online: http://siteresources. worldbank.org/INTPOVERTY/Resources/335642-1124115102975/1555199-1124115187705/vol1.pdf (accessed on 27 October 2015).

35. António Guterres. "UNHCR, faith-based organizations agree to expand cooperation on world's displaced." United Nations High Commission for Refugees, 14 December 2012. Available online: http://www.unhcr. org/cgibin/texis/vtx/search?page=search\&docid=50cadf419\&query=dialogue\%20faith (accessed on 27 October 2015).

36. Estella Carpi. "The political and the humanitarian in Lebanon: Social responsiveness to emergency crisis from the 2006 war to the Syrian refugee influx." Oriente Moderno 94 (2014): 402-27. [CrossRef]

37. Lori-Anne Corkum, and Katie Hunt. "Imagining Our Future Together: Changing the Social Imaginary through Hope." Journal of Religion and Culture: Conference Proceedings 1 (2011): 41-58.

38. John Micklethwait, and Adrian Wooldridge. God is Back: How the Global Revival of Faith is Changing the World. New York: Penguin, 2009.

39. Gordon H. Hanson, and Chong Xiang. "Exporting Christianity: Governance and doctrine in the globalization of US denominations." National Bureau of Economic Research, April 2010. Available online: http:/ /www.nber.org/papers/w16964 (accessed on 27 October 2015).

40. Steve Brouwer, Paul Gifford, and Susan D. Rose. Exporting the American Gospel: Global Christian Fundamentalism. New York: Routledge, 1996.

41. Lex Rieffel, and Sarah Zalud. "International Volunteering: Smart Power." Policy Brief \#155, Brookings Institute Policy, June 2006. Available online: http://reliefweb.int/sites/reliefweb.int/files/resources/ 11B04DF19242BE108525719B0056F19F-br-volunteer-jun2006.pdf (accessed on 27 October 2015).

42. A. Scott Moreau, Gary R. Corwin, and Gary B. McGee, eds. Introducing World Missions: A Biblical, Historical and Practical Survey. Grand Rapids: Baker Academic, 2004.

43. Rachel Hutchins-Viroux. "International NGOs and national attachment in the global age: The evolution of community sentiment in the United States." Studies in Ethnicity and Nationalism 10 (2010): 19-37. [CrossRef]

44. Benjamin J. Lough. International Volunteering from the United States between 2004 and 2012. St. Louis: Center for Social Development, Washington University, 2010.

45. Nancy Gard McGehee, and Carla Almeida Santos. "Social change, discourse and volunteer tourism." Annals of Tourism Research 32 (2005): 760-79. [CrossRef]

46. Damon P. Coppola. Introduction to International Disaster Relief Management. Oxford: Elsevier, 2007. 
47. Patricia J. Owens, Anthony Forgione Jr., and Susan Briggs. "Challenges of international disaster relief: Use of a deployable rapid assembly shelter and surgical hospital." Disaster Management Response 3 (2005): 11-16. [CrossRef] [PubMed]

48. Giving USA: The Annual Report on Philanthropy for the Year 2014. Chicago: Giving USA Foundation, 2015.

49. Giving USA: The Annual Report on Philanthropy for the Year 2013. Chicago: Giving USA Foundation, 2014.

50. Elizabeth Ferris. "Faith-based and secular humanitarian organizations." International Review 87 (2005): 311-25. [CrossRef]

51. Mark Chaves, and Shawna L. Anderson. “Continuity and change in American congregations: Introducing the second wave of the national congregations study." Sociology of Religion 69 (2008): 415-40. [CrossRef]

52. Ian Smillie, and Larry Minear. Charity of Nations. Bloomfield: Kumarian, 2004.

53. Guidestar Advanced Search. Available online: http://www.guidestar.org/SearchResults.aspx (accessed on 8 December 2015).

54. Paul Bennell, Jeanne Harding, and Shirley Rogers-Wright. PRSP Education Sector Review. Freetown: British Council Sierra Leone, 2004.

55. Holger Daun. "Primary education in Sub-Saharan Africa-A moral issue, an economic matter, or both?" Comparative Education 36 (2000): 37-53. [CrossRef]

56. Nelson Mandela. "Together on the way." Address by President Nelson Mandela to the WCC on the occasion of its 50th anniversary, Harare, Zimbabwe, 13 December 1998.

57. Hastings. The Church in Africa, 1495-1950. Oxford: Oxford University Press, 1994.

58. Roy Mersland, Bert D'Espallier, and Magne Supphellen. "The effects of religion on development efforts: Evidence from the microfinance industry and a research agenda." World Development 41 (2013): 145-56. [CrossRef]

59. Abigail Barr, Marcel Fafchamps, and Trudy Owens. "The governance of non-governmental organizations in Uganda." World Development 33 (2005): 657-79. [CrossRef]

60. Robert D. Woodberry. "The missionary roots of liberal democracy." American Political Science Review 106 (2012): 244-74. [CrossRef]

61. Dena Freeman. "Pentecostalism and Economic Development in Sub-Saharan Africa." In The Routledge Handbook of Religions and Global Development. Edited by Emma Tomlin. Oxford: Taylor \& Francis, 2015. Available online: https://www.routledgehandbooks.com/doi/10.4324/9780203694442.ch8 (accessed on 21 January 2016).

62. Carlo Benedetti. "Islamic and Christian inspired relief NGOs: Between tactical collaboration and strategic diffidence?" Journal of International Development 18 (2006): 849-59. [CrossRef]

63. Abdel-Rahman Ghandour. "Humanitarianism, Islam and the West: Contest or cooperation?" Humanitarian Exchange 25 (2003): 14-17.

64. Jon Bennet. Meeting Needs: NGO Coordination in Practice. London: Earthscan, 1995.

65. A. Strand. "Bridging the Gap between Islamic and Western NGOs Working in Conflict Areas." Master's degree Dissertation, University of York, York, UK, 1998.

66. Marian Leonardo Lawson. "Foreign aid: International donor coordination of development assistance." 5 February 2013. Available online: http:/ /fpc.state.gov/documents/organization/205216.pdf (accessed on 27 October 2015).

67. Andreas Hasenclever, and Volker Rittberger. "Does religion make a difference? Theoretical approaches to the impact of faith on political conflict." Millennium: Journal of International Studies 29 (2000): 641-74. [CrossRef]

68. Eli Berman, and David D. Laitin. "Religion, terrorism and public goods: Testing the club model." Journal of Public Economics 92 (2008): 1942-67. [CrossRef]

69. Sudhis Kakar. The Color of Violence: Cultural, Identities, Religion, and Conflict. Chicago: University of Chicago Press, 1996.

70. Jeffrey Haynes. Faith-based Organizations at the United Nations. New York: Palgrave Macmillan, 2014.

(C) 2016 by the authors; licensee MDPI, Basel, Switzerland. This article is an open access article distributed under the terms and conditions of the Creative Commons by Attribution (CC-BY) license (http://creativecommons.org/licenses/by/4.0/). 